University of Nebraska - Lincoln

DigitalCommons@University of Nebraska - Lincoln

Faculty Publications from the Harold W. Manter Laboratory of Parasitology

1996

\title{
The Synlophe and Other Structural Characteristics of Sarwaria bubalis (Nematoda: Trichostrongyloidea) from Cattle in Guyana
}

J. Ralph Lichtenfels

Animal Parasitic Disease Lab, ARS, United States Department of Agriculture, 2jrcgl@gmail.com

Eric P. Hoberg

United States Department of Agriculture, ehoberg@ggpl.arsusda.gov

Patricia A. Pilitt

Animal Parasitic Disease Lab, ARS, United States Department of Agriculture, ppilitt@anri.barc.usda.gov

T. M. Craig

Texas A\&M Universit

Follow this and additional works at: https://digitalcommons.unl.edu/parasitologyfacpubs

Part of the Parasitology Commons

Lichtenfels, J. Ralph; Hoberg, Eric P.; Pilitt, Patricia A.; and Craig, T. M., "The Synlophe and Other Structural Characteristics of Sarwaria bubalis (Nematoda: Trichostrongyloidea) from Cattle in Guyana" (1996).

Faculty Publications from the Harold W. Manter Laboratory of Parasitology. 636.

https://digitalcommons.unl.edu/parasitologyfacpubs/636

This Article is brought to you for free and open access by the Parasitology, Harold W. Manter Laboratory of at DigitalCommons@University of Nebraska - Lincoln. It has been accepted for inclusion in Faculty Publications from the Harold W. Manter Laboratory of Parasitology by an authorized administrator of DigitalCommons@University of Nebraska - Lincoln. 


\title{
THE SYNLOPHE AND OTHER STRUCTURAL CHARACTERISTICS OF SARWARIA BUBALIS (NEMATODA: TRICHOSTRONGYLOIDEA) FROM CATTLE IN GUYANA
}

\author{
J. R. Lichtenfels, E. P. Hoberg, P. A. Pilitt, and T. M. Craig* \\ USDA, Agricultural Research Service, Livestock and Poultry Sciences Institute, \\ Beltsville, Maryland 20705-2350
}

\begin{abstract}
The synlophe (longitudinal, surface cuticular ridges) of Sarwaria bubalis is described for the first time. It is a tapering lateral synlophe of about 40 ridges. The synlophe of $S$. bubalis is similar to that of Ostertagia ostertagi but markedly different from that of species of Spiculopteragia and Mazamastrongylus. New information is provided also on the structure of the esophagus and perivulval pores. The esophageal valve is more than twice as long as wide. The bilateral perivulval pores were located 192$267 \mu \mathrm{m}$ posterior to the vulva and dorsal to the lateral lines. The new information will be useful in a study of the generic level systematics of the Ostertagiinae. Sarwaria bubalis appears to be well established in tropical South America where it infects its normal host, the Asian water buffalo Bubalus bubalis, as well as domestic cattle Bos taurus and mixed breed cattle $B$. taurus $\times$ Bos indicus.
\end{abstract}

Nematodes of the subfamily Ostertagiinae were collected in 1974 from 16 of 21 cattle of mixed breeding (Bos taurus L. $\times$ Bos indicus L.) in Georgetown, Guyana. Nematodes of this subfamily are generally recognized as the most economically important gastrointestinal parasites of cattle. However, they are not encountered often in tropical areas and the literature concerning the presence of Ostertagiinae in these areas is sparse. It was determined that the nematodes differed from Ostertagia ostertagi, the species commonly encountered in cattle. The nematodes were subsequently identified as Sarwaria bubalis (Sarwar, 1956) Dróżdż, 1965.

Sarwaria bubalis is primarily a parasite of the water buffalo, Bubalus bubalis (L.). It was described from that host in Pakistan as Gruhneria bubalis Sarwar, 1956. Dróżdż (1965) reported this nematode in $B$. bubalis in Vietnam and created a new genus, Sarwaria, for it. Sarwaria bubalis was reported from its type host B. bubalis in Venezuela in 1986 (de Moreno, 1986). Hinaidy and Prosl (1981) proposed that Skrjabinagia boevi Pande and Chauhan, 1969, also described from B. bubalis, is a synonym of $S$. bubalis. Durette-Desset $(1983,1989)$ and Jansen (1986) considered both Sarwaria and Skrjabinagia to be synonyms of Spiculopteragia. However, we prefer to follow Dróżdż (1965) and Gibbons and Khalil (1982) in recognizing Sarwaria for $S$. bubalis until a phylogenetic analysis of the Ostertagiinae is completed.

As part of a study of the systematics of the Ostertagiinae in progress in this laboratory, the synlophe, perivulval pores, and characteristics of the esophagus of $S$. bubalis are described for the first time. Other morphological characteristics adequately described by Sarwar (1956) or Dróżdż (1965) for S. bubalis or by Pande and Chauhan (1969) for $S$. boevi are described only briefly.

\section{MATERIALS AND METHODS}

Abomasa from 21 cattle killed at the Georgetown, Guyana, municipal abattoir were collected in 1974 and washed; 2 1:20 aliquots of contents were taken and fixed in $10 \%$ formalin. The cattle were of mixed breeding

Received 22 May 1995; revised 28 August 1995; accepted 28 August 1995.

* Texas A\&M University, Department of Veterinary Pathobiology, College Station, Texas 77843-4467. of both $B$. taurus and $B$. indicus ancestry, ranging in age from 1 to more than 6 yr. Additional specimens of $S$. bubalis from the type host, $B$. bubalis were obtained from Dr. Jan Dróżdż (Dróżdż, 1965).

Specimens were studied as: (1) temporary whole mounts cleared in phenol-alcohol ( 80 parts melted phenol crystals and 20 parts absolute ethanol) and examined with regular light microscopy or interferencecontrast microscopy at a magnification of 400-1,600; and (2) cross sections in free-hand cuts made with a cataract knife and mounted in glycerine jelly.

Male specimens were identified to species on the basis of the morphology of the copulatory bursa, spicules, and genital cone (Sarwar, 1956; Dróżdż, 1965) prior to study of the synlophe and esophagus. Bursal ray patterns were determined and described using the system of Durette-Desset and Chabaud (1981). Papillae of the genital cone and rays of the copulatory bursa followed the numbering system of Chabaud et al. (1970). The lengths of the esophageal-intestinal (E-I) valves, determined to extend from the posterior end of the cuticular lining of the triradiate lumen of the esophagus to the posterior end of the esophagus (Fig. 7), were measured (Tables I, II). Female nematodes were identified on the basis of the morphology of the synlophe, ovejectors, and tail length (Lichtenfels and Pilitt, 1991; Table II). For measurements of the infundibula and sphincters of the ovejectors (Table II), the edge of the muscular portion of the sphincter was used as a dividing line between them, and the fluffy coat around the sphincter and the portion of the infundibulum overlapped by the muscles of the sphincters were ignored (Fig. 9). Because the separation of the vestibule from the sphincter was difficult or impossible to determine, the vestibule was counted as part of the sphincter. The measurement for length of the sphincter includes the distance from the distal end of the sphincter to the vulva. Measurements are in micrometers unless indicated otherwise.

\section{RESULTS}

\section{General characters}

Nematodes of the species $S$. bubalis were found in 16 of the 21 abomasa examined. A mean of 151 adult worms was found in each infected abomasum.

The synlophe of $S$. bubalis consists at the anterior end in the region of the esophagus of 24-44 longitudinal ridges (Figs. 1, 2) with the smaller number anteriorly. The pattern observed is the tapering lateral synlophe or type I (Lichtenfels et al., 1988). The synlophe is divided into 8 fields by continuous ventral, dorsal, 2 lateral, 2 subventral, and 2 subdorsal ridges (dotted in Figs. $1,2)$. The tapering lateral synlophe is so named because ridges in the lateral fields are angled posteriorly toward, and end adjacent to, the slightly thinner lateral ridge, which runs just ventral to the anterior deirid or cervical papilla. The tapering pattern 

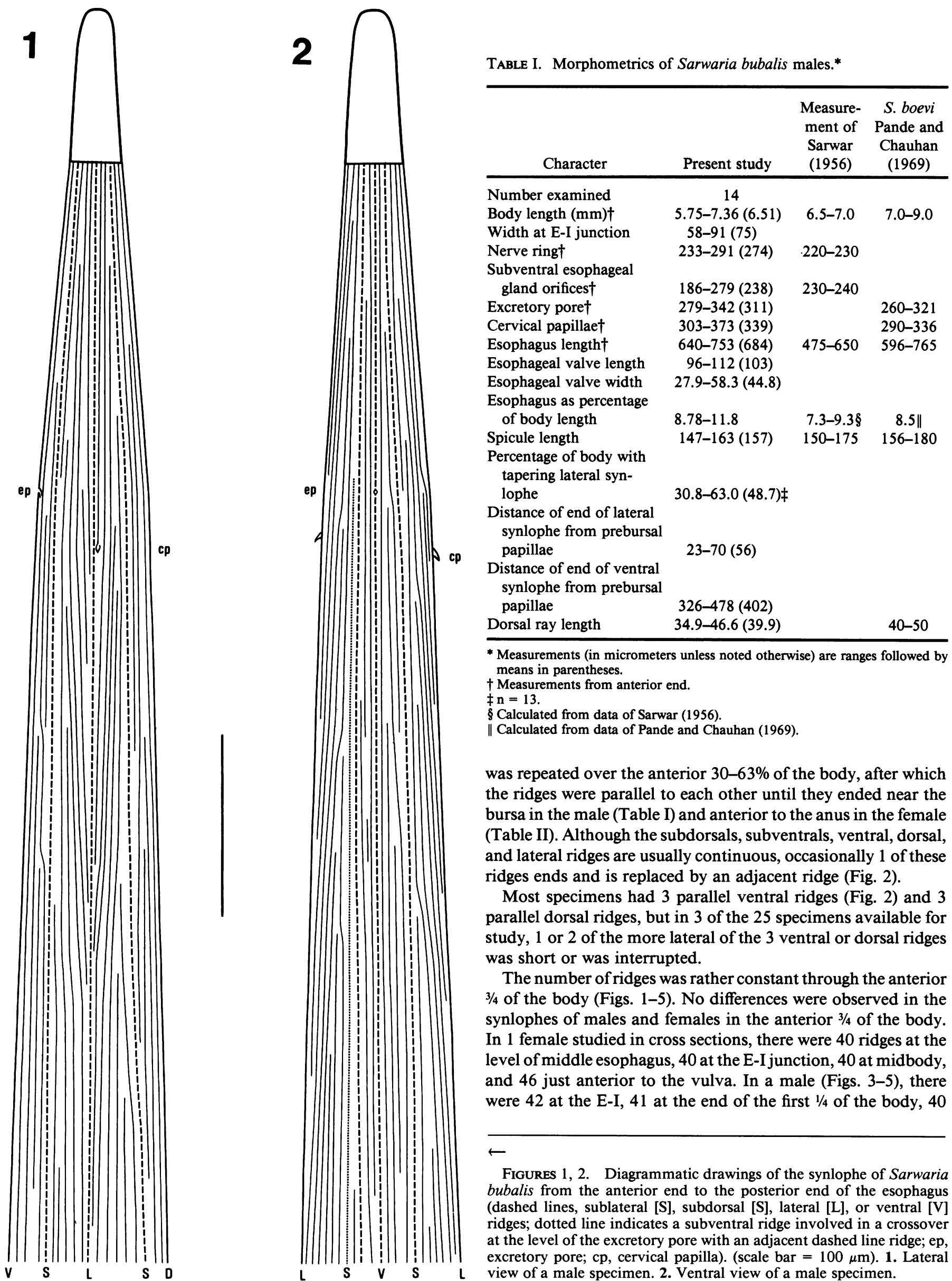

was repeated over the anterior $30-63 \%$ of the body, after which the ridges were parallel to each other until they ended near the bursa in the male (Table I) and anterior to the anus in the female (Table II). Although the subdorsals, subventrals, ventral, dorsal, and lateral ridges are usually continuous, occasionally 1 of these ridges ends and is replaced by an adjacent ridge (Fig. 2).

Most specimens had 3 parallel ventral ridges (Fig. 2) and 3 parallel dorsal ridges, but in 3 of the 25 specimens available for study, 1 or 2 of the more lateral of the 3 ventral or dorsal ridges was short or was interrupted.

The number of ridges was rather constant through the anterior $3 / 4$ of the body (Figs. 1-5). No differences were observed in the synlophes of males and females in the anterior $3 / 4$ of the body. In 1 female studied in cross sections, there were 40 ridges at the level of middle esophagus, 40 at the E-I junction, 40 at midbody, and 46 just anterior to the vulva. In a male (Figs. 3-5), there were 42 at the E-I, 41 at the end of the first $1 / 4$ of the body, 40

FIGURES 1, 2. Diagrammatic drawings of the synlophe of Sarwaria bubalis from the anterior end to the posterior end of the esophagus (dashed lines, sublateral [S], subdorsal [S], lateral [L], or ventral [V] ridges; dotted line indicates a subventral ridge involved in a crossover at the level of the excretory pore with an adjacent dashed line ridge; ep, excretory pore; $c p$, cervical papilla). (scale bar $=100 \mu \mathrm{m}$ ). 1. Lateral view of a male specimen. 2 . Ventral view of a male specimen. 

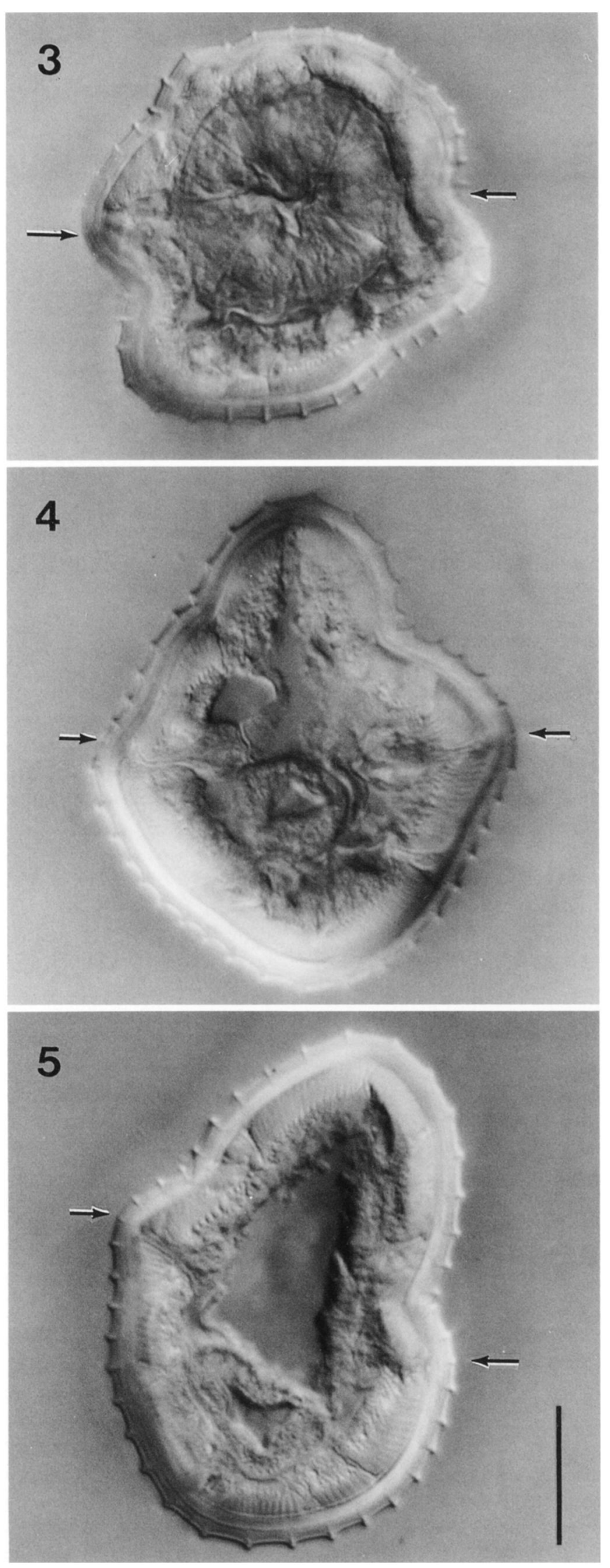

at midbody, and 40 at the beginning of the last quarter of the body.

Two characteristics of the esophagus are described for the first time. The E-I valve was found to be more than twice as long as wide (Fig. 7; Tables I, II). The subventral esophageal gland orifices were anterior to the excretory pore and slightly posterior to the nerve ring (Tables I, II). The length of the esophagus as a percentage of total body length was $7.7-9.1 \%$ in females and $8.8-11.8 \%$ in males.

\section{Male characters}

We confirmed the absence of a gubernaculum, but the dorsal wall of the cloaca is thickened in the area where a gubernaculum would be located. The paired spicules are mirror images of each other and, as in all members of the Ostertagiinae, end in the distal third with 3 branches. The main spicular shaft continues as the longest branch that ends distally in a medially curved tip encased in a fleshy pad. The 2 medially directed alae of the central shaft end in nearly equal branches of which the ventral is a thin sharp tip and the dorsal is a thickened, blunt, spadelike tip (Figs. 16-20). The ventral branch ends in an acute point, with the shaft curved strongly medially; the thin tip is bordered by a crenulated membrane supported by prominent trabeculae. Although the thin tip of the ventral branch curves dorsomedially, in ventral view (Fig. 19) it may appear to be straight. The dorsal branch is wide, highly cuticularized, with a prominent transverse bar dorsally, a ventrally curved apex, and a membranous crenulated margin distal to the sclerotized tip (Figs. 18, 20).

The rays of the bilaterally symmetrical lateral bursal lobes are in a 2-2-1 pattern with the anterolateral ray (no. 4) of each lobe ending bluntly short of the edge of the bursa (Figs. 13-15). The posterolateral rays (no. 6) are the longest rays of the bursa. The externodorsal rays (no. 8) are only half as long as the posterolaterals. The dorsal ray is very short (Table I) and is bifurcated for more than half its length, each branch ending in a trifurcate tip. The genital cone lacks a proconus. The ventral part of the genital cone bears paired, slender, curved papillae (no. 0) enclosed, except for the distal tips within a bubble-like membrane (Figs. 15, 21, 22). The dorsal part of the genital cone bears paired finger-like papillae (no. 7) enclosed, except for the distal tips, within the accessory bursal membrane (Figs. 15, 21, 23). In lateral view, the dorsal ray can be seen curved ventrally just dorsal to the accessory bursal membrane (Figs. 14, 21). A telamon, or sclerotized internal support for the ventral part of the genital cone, is just anterior to the paired "O" papillae (Figs. $14,15)$. There is also a bowl-shaped, internal, sclerotized support for the dorsal part of the genital cone just anterior to the accessory bursal membrane and the no. 7 papillae (Fig. 23).

\section{Female characters}

The vulva is located at $80-87 \%$ of body length from the anterior end. The vulva is a transverse opening without lobes,

Figures 3-5. Cross sections of a male Sarwaria bubalis (arrows at lateral ridges) (scale bar $=20 \mu \mathrm{m}$ ). 3. Through posterior esophagus showing 42 ridges. 4 . At one-fourth of body length from anterior end showing 41 ridges. 5 . At midbody showing 40 ridges. 
TABLE II. Morphometrics of Sarwaria bubalis females.*

\begin{tabular}{|c|c|c|c|}
\hline Number examined & 11 & & \\
\hline Width at E-I junction & $72-98(83)$ & & \\
\hline Nerve ring $\dagger$ & $224-314(266)$ & $250-280$ & \\
\hline Subventral esophageal gland orifices $\dagger$ & $189-291(240)$ & $300-340$ & $280-310$ \\
\hline Esophagus length $\dagger$ & $648-746(692)$ & $650-700$ & $642-765$ \\
\hline Esophageal valve length & $93-124(110)$ & & \\
\hline Esophageal valve width & $41.9-58.3(49.6)$ & & \\
\hline Esophagus as percentage of body length & $7.71-9.06(8.25)$ & $7.8-8.1$ & $7.0-7.1 \S$ \\
\hline Vulva position (percentage) & $80.3-87.0(85.1)$ & & $83.4-84.1 \S$ \\
\hline Anterior infundibulum length & $131-196(164)$ & & \\
\hline Combined ovejector length & $477-594(524)$ & $575 \|$ & $500 \S$ \\
\hline Egg length $\times$ width & $72-87(78) \times 36-46(30) \ddagger$ & $85-95 \times 45-50$ & $78-91 \times 37-48$ \\
\hline Number of eggs in anterior uterus & $6-15(10)$ & & \\
\hline Number of eggs in posterior uterus & $6-16(9)$ & & \\
\hline Tail length & $84-114(101)$ & & $122-149$ \\
\hline $\begin{array}{l}\text { Percentage of body with a tapering lateral syn- } \\
\text { lophe }\end{array}$ & $30-61(41)$ & & \\
\hline Distance of end of lateral synlophe from tail tip & $108-384(232)$ & & \\
\hline
\end{tabular}

* Measurements (in micrometers unless noted otherwise) are ranges followed by means in parentheses.

$\dagger$ Measurement from anterior end.

$\ddagger \mathrm{n}=7$.

$\$$ Calculated from data of Pande and Chauhan (1969).

\| Calculated from drawing in Sarwar (1956).

flaps, knobs, or other ornamentations. The vagina is short with a thick cuticular lining (Fig. 9). The vestibule is short, deeper than long. Because the boundaries of the vestibule are difficult to distinguish from the adjacent sphincters, it was not measured separately. The sphincters are thick-walled and lined with thick cuticle. Each sphincter consists of an oval, wider than long, bulblike valve next to the infundibulum and a longer barrelshaped extension that connects with the short vestibule (Fig. 9). The infundibula were less than half as thick and 50\% longer than the sphincters. The anterior sphincter and infundibulum were slightly longer than their posterior counterparts (Table II).

Eggs were usually present in both anterior and posterior uteri. Uterine eggs were oval-shaped and usually in the 32-64-cell stage of development (Fig. 11).

Perivulval pores (Lichtenfels et al., 1995) (Fig. 10) were present bilaterally in the females. The pores were located 192-267 $\mu \mathrm{m}$ posterior to the vulva, slightly dorsal to the lateral ridge, at or near the level of the posterior infundibulum.

The tail was found to be short, conical, and usually with a rounded digitiform tip (Fig. 12). The posterior end of the females had a marked ventral curvature (Fig. 12).

\section{DISCUSSION}

New information on $S$. bubalis presented herein includes the description of the synlophe, esophagus, and perivulval pores
(Lichtenfels et al., 1995). The new information makes it possible to compare $S$. bubalis with other Ostertagiinae with a tapering lateral synlophe (Lichtenfels and Pilitt, 1991; Lichtenfels et al., 1993; Lichtenfels and Hoberg, 1993). This new information is also required for a phylogenetic analysis of the Ostertagiinae, an essential study for determining the generic level systematics of this subfamily.

The synlophe of $S$. bubalis is very similar in the region of the esophagus to the tapering lateral synlophe described earlier (Lichtenfels et al., 1988) for Ostertagia ostertagi and Teladorsagia circumcincta (Stadelmann, 1894), and for Ostertagia bisonis Chapin, 1925 by Lichtenfels and Pilitt (1991). The aforementioned species all have continuous subventral and subdorsal ridges that, with the lateral ridges and the dorsal and ventral ridges, divide the synlophe into 8 fields of mostly shorter ridges. The synlophe of $S$. bubalis differs significantly, however, from the tapering lateral synlophe of Mazamastrongylus spp. described by Lichtenfels et al. (1993), which lacks the continuous subdorsal and subventral ridges. In Mazamastrongylus spp., the synlophe is divided into only 4 fields by the 2 lateral and the dorsal and ventral ridges (Lichtenfels et al., 1993). A pattern similar to that of Mazamastrongylus spp. has been observed in several species of Spiculopteragia (E. P. Hoberg, unpubl. obs.). Most Ostertagiinae with a tapering lateral synlophe have the pattern seen in $S$. bubalis, $O$. ostertagi, $O$. bisonis, Teladorsagia circumcincta, and others. The pattern described for Mazama- 


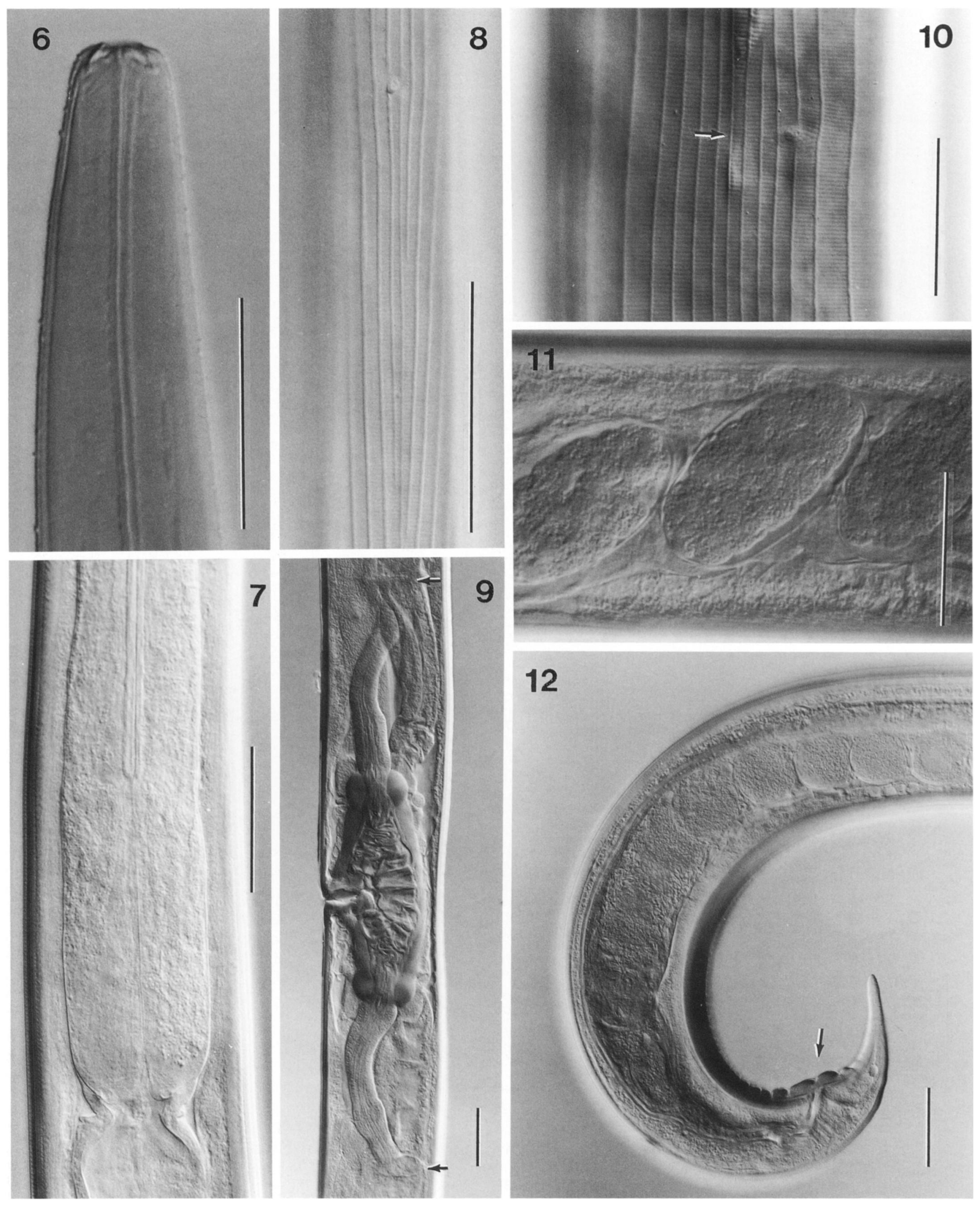




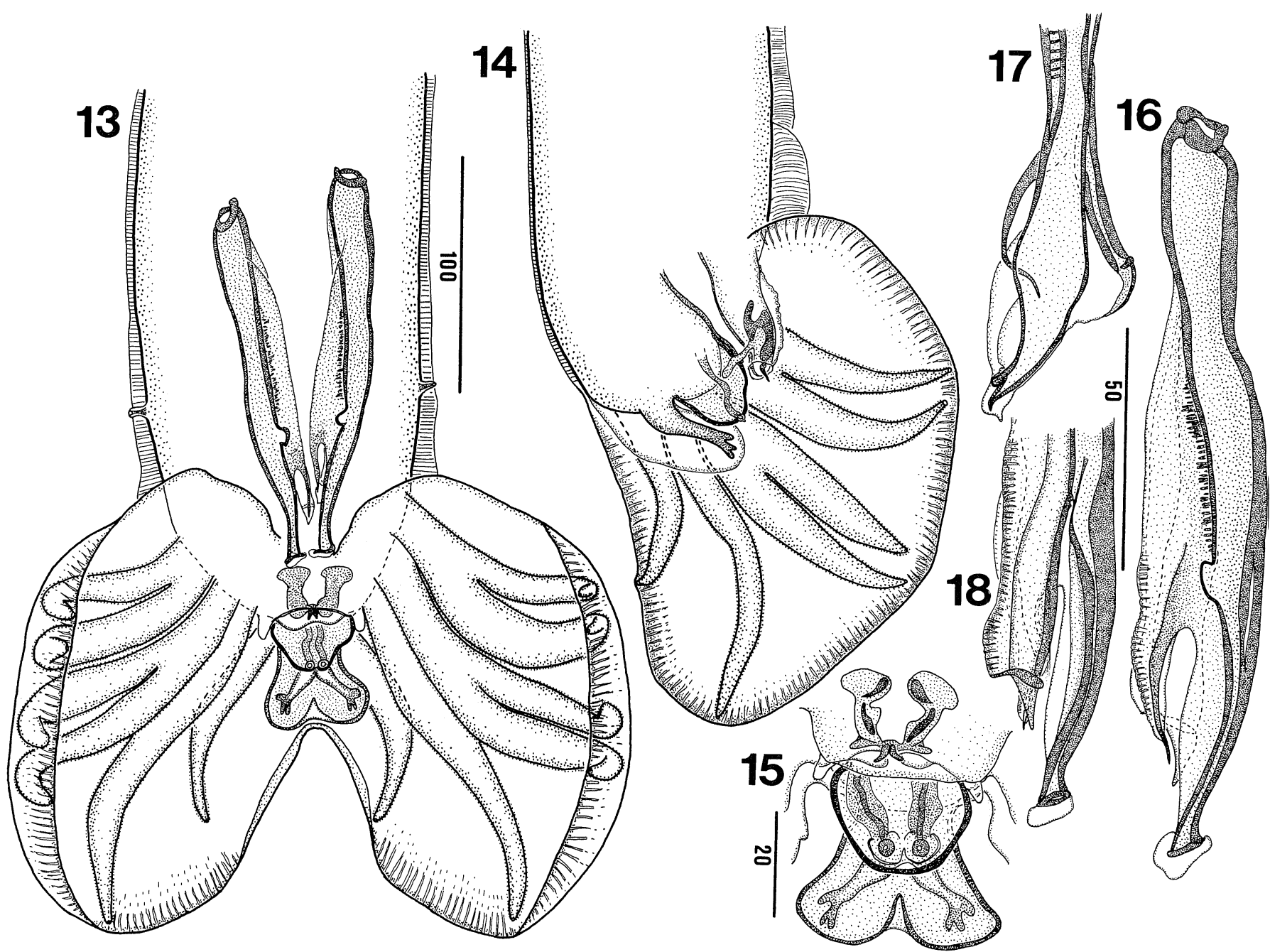

FIGURES 13-18. Camera lucida drawings of male characteristics of Sarwaria bubalis. 13. Posterior end, ventral view of copulatory bursa, genital cone, and spicules. 14. Lateral view of bursa and genital cone. 15. Genital cone and dorsal-ray, ventral view. 16. Left spicule, ventral view. 17. Distal half of left spicule, lateral view. 18. Distal half of right spicule, dorsal view.

strongylus and reported for Spiculopteragia has been seen only in members of these 2 genera and in all members of these genera that have been examined by us.

A discussion of the generic level systematics of the Ostertagiinae is needed but is beyond the scope of this paper. It was necessary, however, to decide which genus should be used for the species redescribed here. As we explained earlier, S. bubalis has been placed in various genera, including Gruhneria, Sarwaria, Skrjabinagia, and Spiculopteragia. We agree with Dróżdż (1965) and others in considering Gruhneria a synonym of Ostertagia and with Durette-Desset (1983) in considering Skrja- binagia a synonym of Spiculopteragia. However, we disagree with Durette-Desset $(1983,1989)$ and Jansen (1986) who considered Sarwaria a synonym of Spiculopteragia. We decided to follow Dróżdż (1965) and Gibbons and Khalil (1982) in recognizing Sarwaria as a separate genus for this species. We based this decision on the marked differences between the synlophe and spicules of $S$. bubalis and those of Mazamastrongylus spp. and Spiculopteragia spp. Characteristics such as the extremely short dorsal ray and short, thick bursal ray no. 4 distinguish Sarwaria from Teledorsagia and Ostertagia. We believe a phylogenetic analysis is required to determine a suitable generic

FiguREs 6-12. Photomicrographs of general and female characteristics of Sarwaria bubalis. All scale bars $50 \mu \mathrm{m} .6$. Anterior end, lateral view, of female showing short buccal capsule and dorsal esophageal tooth. 7. Esophageal valve, lateral view, of male. 8. Lateral ridges of synlophe in region of anterior deirid (=cervical papilla). Lateral ridge ventral (right) to deirid. 9. Vulva and ovejectors, lateral view. Arrows indicate distal ends of infundibula. 10. Perivulval pore on left side of female. Note spacing of ridges of synlophe with lateral ridges closer than dorsal, and ventral ridges. Arrow at lateral ridge points to more dorsal perivulval pore. 11. Eggs in uterus. 12. Ventrally curved tail, and posterior body of female. Arrow at anus. 

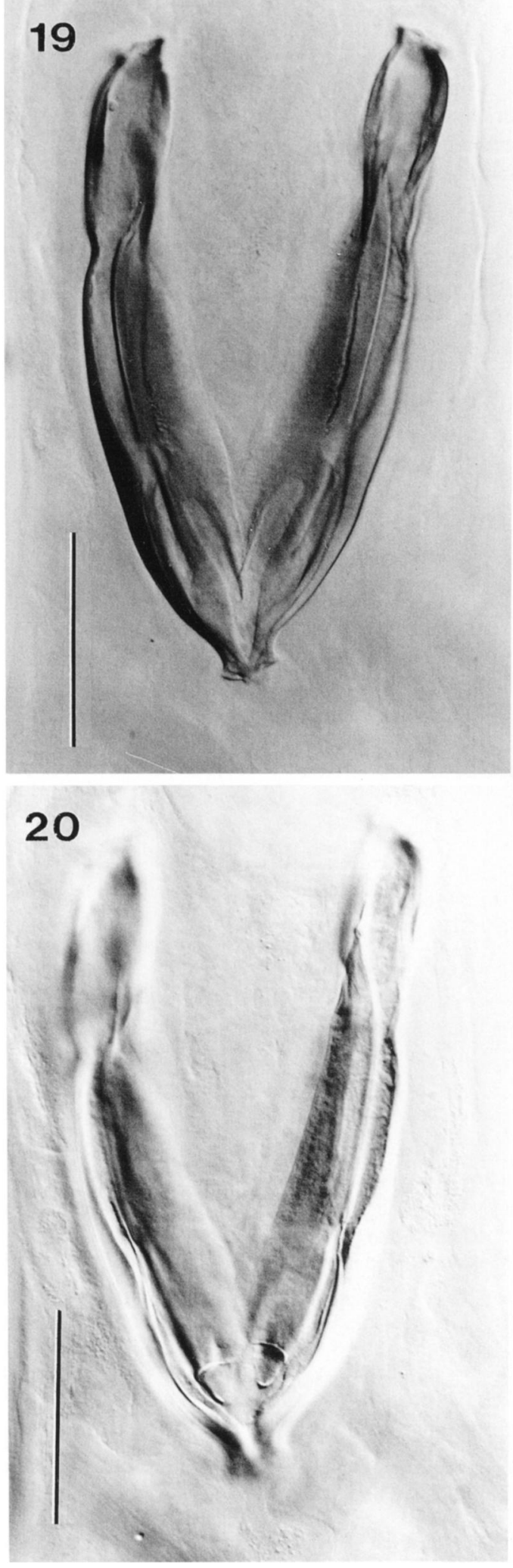
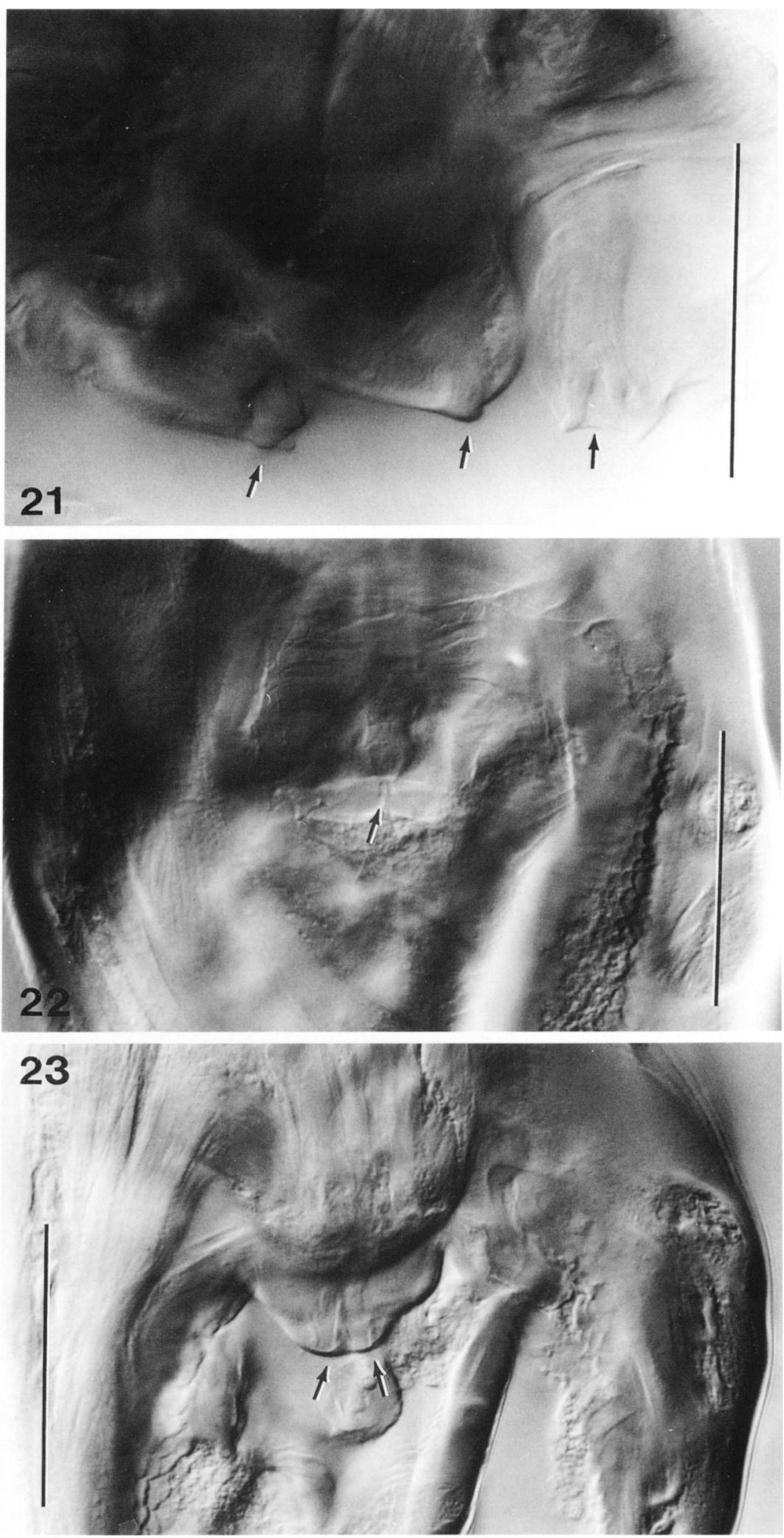

FIGURES 19-23. Photomicrographs of male characteristics of Sarwaria bubalis. All scale bars $50 \mu \mathrm{m}$. 19. Spicules showing spinelike ventral branch of each spicule, ventral view. 20. Spicules showing triangular thickened tips of dorsal branch of each spicule in ventral view. 21. Genital cone, left lateral view showing tips of 1 of paired "O" papillae (left arrow), tip of 1 of paired no. 7 papillae (middle arrow), and the left branch of the dorsal ray with 3 digitate tips (right arrow). 22. Genital cone, ventral view, showing tiny paired "O" papillae within membrane (arrow). 23. Genital cone, ventral view, showing paired no. 7 papillae within accessory bursal membrane (arrows). 
level taxonomy for the Ostertagiinae. Until this is completed, however, the differences observed between the synlophe $S$. bubalis and those of Mazamastrongylus and Spiculopteragia require retaining Sarwaria.

The esophageal valve of $S$. bubalis is more than twice as long as wide. This character, among others, can be used to separate this species from both $O$. ostertagi and $T$. circumcincta. Among the Ostertagiinae reported from cattle in the western hemisphere, the esophageal valve of $S$. bubalis is similar to that of $O$. bisonis among species, with a tapering lateral synlophe and also similar to several species with parallel or type II synlophes, including Marshallagia marshalli (Ransom, 1907) and O. leptospicularis Asadov, 1953. Other Ostertagiinae parasitic in cervids also have a long esophageal valve (Lichtenfels and Hoberg, 1993). Ostertagia bisonis differs significantly from $S$. bubalis in the former species' long dorsal ray and 2-2-1 lateral bursal ray pattern in the male and the much longer ovejector in the female (Lichtenfels and Pilitt, 1991).

The location of the perivulval pores at the level of the posterior infundibulum and slightly dorsal to the lateral line is similar to their location (Lichtenfels et al., 1995) in other Ostertagiinae. The function of the perivulval pores is unknown, but their location has been a useful species-level systematic character (Handoo and Golden, 1992) in plant parasites of the family Tylenchidae. Among the Ostertagiinae, perivulval pores have been described in $O$. ostertagi by Lichtenfels et al. (1995) herein for $S$. bubalis and have been observed (J. R. Lichtenfels, unpubl. obs.) in Mazamastrongylus odocoilei. In all 3 species of Ostertagiinae, the perivulval pores were located in similar locations. Furthermore, the perivulval pores were also located in closely similar positions to that described for the 3 ostertagines in other species of Trichostrongylidae, including (Lichtenfels et al., 1995) 3 species of Haemonchus and Cooperia oncophora. In Trichostrongylus colubriformis, however, the perivulval pores were located slightly anterior to the vulva in a dorsolateral position equivalent to that of the other trichostrongylids. Conclusions about the systematic value of perivulval pores within the Trichostrongylidae must await their description in more species. This newly described character (Lichtenfels et al., 1995) should be included in all future descriptions of nematodes of the class Secernentea.

The vulval region of all $S$. bubalis females available for study were without ornamentation such as lobes, flaps, or knobs. However, Pande and Chauhan (1969) described a "small rounded vulvar flap in $4.5 \%$ of Skrjabinagia boevi, which is believed to be a synonym of $S$. bubalis. Michel et al. (1972a, 1972b) described considerable variation in the development of $O$. ostertagi and populations of a species with smooth vulvas cannot be considered to be indicative of the absence of vulval ornamentation for the entire species.

The posterior ovejector of $S$. bubalis was found to be slightly shorter than the anterior. This asymmetry is common in the Ostertagiinae (Lichtenfels and Pilitt, 1991).

The geographic distribution of $S$. bubalis appears to coincide with that of its type host $B$. bubalis, but the present report and that of Bryan et al. (1976) demonstrate that this nematode can also infect $B$. taurus. In Australia, Bryan et al. (1976) found $B$. bubalis and Bos taurus to be infected at a similar rate. The present report demonstrates that $S$. bubalis can infect cattle of mixed breed (including $B$. taurus L. $\times$ B. indicus L.). It is curious, however, that $S$. bubalis has apparently not been reported in $B$. indicus in Asia where both $B$. bubalis and $B$. indicus are common. In the course of this study, we examined the published description of Skrjabinagia bubalis Jiang, Guam, Yan and Zhou, 1988 and concluded from the description that it is also a synonym of $S$. bubalis (Sarwar, 1956). Sarwaria bubalis has been reported from $B$. bubalis in the eastern hemisphere in Pakistan (Sarwar, 1956), in India (Pande and Chauhan, 1969), in China (Jiang et al., 1988), in Australia (Bryan et al., 1976), and in Egypt (Michael et al., 1979). In the western hemisphere, $S$. bubalis has also been reported from B. bubalis in Brazil (Costa et al., 1980; Starke et al., 1983; Lima and Guimaraes, 1988), in Venezuela (de Moreno, 1986), and now in Guyana. It is clear that $S$. bubalis has been imported into both South America and Australia with its normal host, $B$. bubalis. Furthermore, $S$. bubalis has become established in both South America and Australia, infecting domestic cattle. Most infections reported to date have been relatively light $(<250)$ and it is not possible to predict the pathogenicity of this nematode in $B$. taurus, especially if the nematode will develop in more temperate regions. So far, $S$. bubalis has been distributed in tropical to subtropical regions where its normal host is distributed.

\section{ACKNOWLEDGMENTS}

Jan Dróżdż, W. Stefánski Institute of Parasitology, Polish Academy of Sciences, Warsaw, Poland, supplied specimens of Sarwaria bubalis for study. Arthur Abrams provided technical assistance.

\section{LITERATURE CITED}

BRyAN, R. P., M. J. BAINBridge, AND J. D. KERR. 1976. A study of helminth parasites in the gastrointestinal tract of the swamp buffalo, Bubalus bubalis Lydekker, in the Northern Territory. Australian Journal of Zoology 24: 417-421.

Chabaud, A. G., F. Puylaert, O. Bain, A. J. Petter, and M. C. DURETTE-DesSET. 1970. Remarques sur l'homologie entre les papilles cloacales des rhabdtides et les côtes dorsales des Strongylida. Comptes Rendus de l'Academie des Sciences Paris 271: 1771-1774.

Costa, A. J., L. J. Pacola, I. G. Arantes, J. Dohara, and C. L. Justo. 1980. Desenvolvimento das helmintoses gastrintestinais em bufalos (Bubalus bubalis L.) nascidos em Sertaozintio (SP). Boletin de Industria Animal 37: 195-205.

DE Moreno, L. G. 1986. Helmintos parasitos de bufalos Bubalus bubalis de los centros de recria del estado Apure, Venezuela. Revista de la Facultad de Ciencias Veterinarias 33: 21-26.

DRóżDż, J. 1965. Studies on helminths and helminthiases in Cervidae. I. Revision of the subfamily Ostertagiinae Sarwar, 1956 and an attempt to explain the phylogenesis of its representatives. Acta Parasitologica Polonica XIII: 445-481.

DuRETTE-Desset, M. C. 1983. Keys to genera of the superfamily Ostertagiinae. In $\mathrm{CIH}$ keys to the nematode parasites of vertebrates. No. 10, R. C. Anderson, and A. G. Chaubaud (eds.). Commonwealth Agricultural Bureaux, Farnham Royal, U.K., 86 pp.

. 1989. Nomenclature proposée pour les espèces décrites dan la sous-famille des Ostertagiinae Lopez-Neyra, 1947. Annales de Parasitologie Humaine et Comparee 64: 356-373.

- , AND A. G. Chabaud. 1981. Nouvel essai de classification des nematodes Trichostrongyloidea. Annales de Parasitologie Humaine et Comparee 56: 297-312.

GibBons, L. M., AND L. F. KHALIL. 1982. A key for the identification of genera of the nematode family Trichostrongylidae Keiper, 1912. Journal of Helminthology 56: 185-233.

HANDOO, Z. A., AND A. M. Golden. 1992. A key, and diagnostic compendium to the species of the genus Hoplolaimus Daday, 1905 (Nematoda: Hoplolaimidae). Journal of Nematology 24: 45-53. 
HinaIdy, H. K., AND H. Prosl. 1981. Systematics of Ostertagia sens. lat. (Nematoda: Trichostrongylidae) (Workshop 14, EMOP 3). Parasitology 82: 181-183.

JANSEN, J. 1986. Redescription of Mazamastrongylus trinitatis Cameron, 1935, and a discussion on the systematic position, and species composition of the genus Mazamastrongylus Cameron, 1935 (Nematoda: Trichostrongyloidea). Systematic Parasitology 8: 279283.

Jiang, X. L., G. J. Guan, J. B. Yan, AND W. L. Zhou. 1988. Notes on 3 new species of Trichostrongylidae of cattle from Sichuan Province, China. Acta Veterinaria et Zootechnica Sinica 19: 57-62. [In Chinese, with English summary.]

Lichtenfels, J. R., AND E. P. Hoberg. 1993. The systematics of nematodes that cause ostertagiasis in domestic, and wild ruminants in North America: An update, and a key to species. Veterinary Parasitology 46: 33-53.

P. A. Pilitt, and A. G. Belem. 1993. A comparison of cuticular ridge patterns, and other morphological characters of Mazamastrongylus odocoilei, and Mazamastrongylus pursglovei (Nematoda: Trichostrongyloidea) from white-tailed deer Odocoileus virginianus. Systematic Parasitology 24: 1-15.

, AND P. A. PILITT. 1991. A redescription of Ostertagia bisonis (Nematoda: Trichostrongyloidea), and a key to species of Ostertagiinae with a tapering lateral synlophe from domestic ruminants in North America. Journal of the Helminthological Society of Washington 58: 231-244.

\footnotetext{
- AND M. B. LANCASTER. 1988. Cuticular ridge patterns
} of seven species of Ostertagiinae (Nematoda) parasitic in domestic ruminants. Proceedings of the Helminthological Society of Washington 55: 77-86.

, W. P. Wergin, C. Murphy, AND P. A. Pilitt. 1995. Bilateral, perivulval cuticular pores in trichostrongylid nematodes. Journal of Parasitology 81: 633-636.

Lima, W. DOS S., AND M. P. GUIMARAes. 1988. Ostertagia trifurcata em bufalos (Bubalus bubalis) de Minas Gerais. Arquivo Brasileiro de Medicina Veterinaria e Zootecnia 40: 443-444.

Michael, S. A., A. H. El Refah, and A. J. Higgins. 1979. Efficacy of oxyfendazole against naturally acquired gastro-intestinal nematode infestations in buffaloes in Egypt. Tropical Animal Health, and Production 11: 159-163.

Michel, J. F., M. B. LANCASTER, AND C. Hong. 1972a. The development, and symmetry of the vulval flap of Ostertagia ostertagi. International Journal for Parasitology 2: 297-304.

$\longrightarrow,-$ AND $\longrightarrow$ 1972b. Host induced effects on the vulval flap of Ostertagia ostertagi. International Journal for Parasitology 2: 305-317.

Pande, B. P., AND P. P. S. Chauhan. 1969. Abomasal lesions in a trichostrongyloid infection of buffalo calves (below two years), and the morphology, and taxonomy of the nematode. Indian Journal of Animal Science 36: 79-88.

SARWAR, M. M. 1956. Studies on some trichostrongylids of ruminants from the Indo-Pakistan subcontinent. Biologia 2: 145-215.

StARKe, W. A., R. Z. MAChado, M. R. Honer, AND M. C. Zocoller. 1983. Curso natural das helmintoses gastrintestinais em bufalos no municipio de Andradina (SP). Arquivo Brasileiro de Medicina Veterinaria e Zootecnia 35: 651-664. 